\title{
Kitap Eleştirisi
}

Caner Yelbaşı

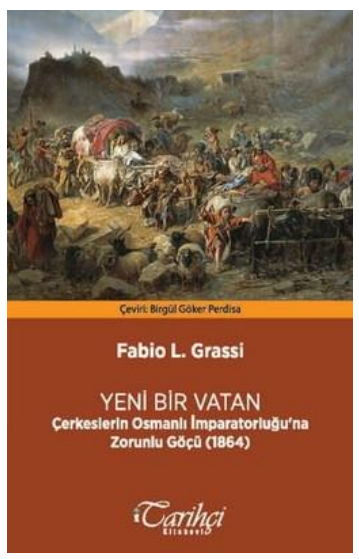

Fabio L. Grassi

Yeni Bir Vatan: Çerkeslerin Osmanlı İmparatorluğu'na Zorunlu Göçü (1864)

(Una Nuova Patria. L'Esodo dei Circassi verso I'Impero Ottomano)

Çev. Birgül Göker Perdisa İstanbul, 2017

ISBN: 9752466005

Tarihçi akademisyen Fabio L. Grassi'nin İtalyancadan Türkçeye çevrilen kitabı sekiz bölümden oluşmaktadır. İlk beş bölüm Rusya'nın Kafkasya'yı işgali sonucu Çerkeslerin Osmanlı İmparatorluğu'na gelmeye başlamasından itibaren Osmanlı'nın son dönemini ve Cumhuriyet dönemini kapsamaktadır. Çerkeslerin başına gelen trajedinin adlandırılmasıyla ilgili akademisyenler arasındaki tartışmalar da ele alınmaktadır. Osmanlı Karantina Cemiyeti'nde görevli olan Dr. Barozzi'nin Fransızca kaleme aldığı notlar ve raporlar ile İngiliz ve İtalyan askeri belgelerinin olduğu üç bölüm de kitabın sonuna eklenmiştir.

Kitabın ilk bölümünde "Çerkesler ile ilgili Temel Bilgiler" başlığı altında Çerkes dili, kültürü ve Çerkes kelimesinin hangi grupları kapsadığı gibi konulardan bahsedilerek Çerkeslerle ilgili bir giriş ve genel bir bilgilendirme yapılmıştır. "Çerkes" adının kullanımıyla ilgili

* Caner Yelbaşı, Dr., Mardin Artuklu Üniversitesi, Tarih Bölümü, Araştırma Görevlisi. E-mail: caneryelbasi@gmail.com (Makale gönderim tarihi: 08.09.2017, makale kabul tarihi: 13.09.2017). 
tartışmalara da giren yazar, bu adın daha çok kendini Adığe olarak adlandıran topluluklar, Ubıhlar ve kendini Çerkes olarak kabul eden Abazalar için kullanıldığını, bütün Kuzey Kafkasyalıların da zaman zaman bu şekilde adlandırıldıklarını belirtmiştir. Yazar kitabını Çerkeslerin Osmanlı topraklarına geliş sürecini siyasi bir yöne taşımadan, soykırım mı göç mü tartışmalarına girmeden, mümkün olduğunca kapsamlı bir anlatımla alana katkı sunmak amacıyla yazdığını belirtmiştir. Ancak bu tanımlama ilk sayfalardan itibaren kitapta bir terminoloji sorununun oluşmasına neden olmuştur. Yazar Rus işgali sonucunda Çerkeslerin Kafkasya'yı terk ederek Osmanlı Imparatorluğu'na göç ettiği tezini benimsemesine rağmen, yaşananları kimi yerde zorunlu göç, kimi yerde sürgün ve hatta sistematik katliamlar olarak tanımlamıştır. Giriş bölümünde bahsedilen kavramlarla ilgili detaylı bir terminolojik tartışma yapılmadığı için yazarın hangi dönemi ya da olayı göç, zorunlu göç, sürgün veya etnik temizlik olarak tanımladığını anlamak okuyucu için zor olmaktadır.

İkinci bölümde Rus-Kafkas savaşlarının 1859 'da İmam Şamil'in teslim olduğu döneme kadar olan dönemi anlatılmakta, Doğu ve Batı Kafkasya'da Rus işgaline karşı ortak bir direniş oluşturulamamasından ve Batı Kafkasya'daki direnişin önde gelen isimlerinden Zanuko Seferbey'in Osmanlı'dan destek alma çabalarından bahsedilmektedir. Akademik bir araştırma kitabı olmasına rağmen, Rus-Kafkas savaşlarının anlatıldığı ikinci bölümde referans olarak çok az sayıda kaynak verilmiştir. Bu yüzden anlatılanların hangi kaynağa ya da arşiv belgesine dayandığını öğrenmek mümkün değildir (s. 37-65).

Üçüncü bölümde Çerkeslerin Rus ordusu karşısında uğradıkları yenilgi ve sonrasında Kafkasya'yı terk etmelerine yol açan süreç "Çerkeslerin Yok Edilmesine Yönelik Hazırlıklar ve Uygulama" başlığı altında anlatılmaktadır. Rus işgal kuvvetlerinin Çerkesleri Kafkasya'yı terke zorlamaları, Osmanlı İmparatorluğu'nun yüz binlerce göçmeni kabul edecek imkanlara ve organizasyona sahip olmaması, Çerkeslerin trajik durumu Meclis-i Umur-u Sıhhiye tarafından sağlık müfettişi olarak görevlendirilen italyan doktor Barozzi'nin notları ve raporları üzerinden anlatılmaktadır. Çerkeslerin limanlarda karşılanması ve Osmanlı topraklarına yerleştirilmesiyle ilgili sayfalarca süren ayrıntılı anlatımlar yapılmakta, ikinci bölümdekine benzer fazlasıyla detaylı bilgiler verilmekte, fakat bunların Dr. Barozzi'nin notlarından ve 
raporlarından $\mathrm{mI}$ yoksa başka kaynaklardan $\mathrm{ml}$ aktarıldığı belirtilmemektedir. Ayrıntılı yorumların hangi belge ve kaynaklara dayanarak yapıldığı sorusu yine cevapsız kalmaktadır. Örneğin General Rotislav A. Fadeyev'e atfedilen ve Çerkes sorununun Çerkeslerin Kuban bölgesinde iskân edilerek mi yoksa Osmanlı’ya gönderilerek mi çözüleceği konusunun tartışıldığı bir rapordan herhangi bir kaynak gösterilmeden bahsedilmektedir (s. 68). Aynı bölümde, bölgenin kolonizasyonunda kullanılan Kazakların Kafkasyalılarla karşı karşıya gelmesi, her iki tarafın hayatta kalabilmek için verdiği bir mücadeleye benzetilmektedir (s. 63). Bilindiği gibi Kazaklar Rusya yönetimi tarafından Kafkasya'nın kolonizasyonu amacıyla yerli halkın topraklarına yerleştirilen bir unsurdur ve Çerkesler gibi hayatta kalabilmek için savaştıkları argümanının gerçeği yansıttığını söylemek zordur.

Dördüncü bölümde Çerkeslerin Osmanlı topraklarına iskânı "Yerleştirme" başlığı altında incelenmiştir. Bu bölümde daha çok, Çerkeslerin yerleştirilmelerinin hem kendileri hem de Anadolu ve Balkanlar'daki diğer halklar için yarattığı sosyo-ekonomik değişikliklerden ve bunların Çerkeslerin bu halklarla kurdukları ilişki üzerine etkisinden bahsedilmektedir. Yazarın da bahsettiği gibi Osmanlı yönetimi her ne kadar Çerkesleri vergi ve güvenlik konularında sıkıntılı bölgelere yerleştirip denetimini artırmayı hedeflemiş olsa da Rusya'nın ve İngiltere'nin baskısı, Anadolu'daki halkların şikayetleri, iyi planlanmış bir iskân politikasının olmayışı, kimi devlet görevlilerinin beceriksizliği ve yolsuzluğu, beklenenin çok üzerinde bir nüfusun gelmesi gibi nedenlerden ötürü Çerkeslerin iskanının sistemli bir şekilde yapıldığını söylemek mümkün değildir. Aynı bölümde Ermenilerle Çerkeslerin Anadolu'da karşı karşıya gelmeleri anlatılmış, Çerkeslerin tutumunun Ermeniler için sürekli bir rahatsızlık nedeni olduğu vurgulanmıştır (s. 108-110).

Beşinci bölümde Çerkeslerin Osmanlı coğrafyasına yerleşmeleri, entegrasyonları, Osmanlı ve Cumhuriyet Dönemleri'nde kurdukları örgütler ve Çerkes kimliğinin imparatorluk ve ulus devlet süreçlerinde uğradığı değişimler ele alınmaktadır. Yazar Çerkes Teavün Cemiyeti ve Çerkes İttihad ve Teavün Cemiyeti'nin iki ayrı cemiyet olduğunu, hatta Çerkes Itttihad ve Teavün Cemiyeti'nin Çerkes Teavün Cemiyeti içerisinden bir grup tarafından kurulduğunu iddia etmektedir (s. 140). 
Ancak ikisi de aynı cemiyettir, tam adı Çerkes İttihad ve Teavün Cemiyeti olan cemiyetten sık sık Çerkes Teavün Cemiyeti olarak bahsedilmesi yazarı hataya düşürmüştür. Yazar aynı bölümde Lozan Antlaşması sonrası yeni rejimin politikalarının asimilasyonist olduğu kadar "dürüst" de olduğunu, Türk kimliğini kabul edip kendi etnik kimliğini kamusal alana taşımayanların herhangi bir ayrımcılığa maruz kalmadığını savunmaktadır (s. 142). Kurtuluş Savaşı bitenceye kadar aslında bir tür Müslüman milliyetçiliğinin benimsendiğine, etnik grupların kimliklerini ifade etmelerinin bu dönemde sorun olarak görülmediğine, ancak savaş bittikten sonra bu politikanın yerine Türk milliyetçiliğinin ve ulus devlet inşa politikasının esas alındığına hiç değinilmemektedir.

Bu bölümün son kısmında yazar, halen devam eden bir tartışma olan Çerkeslerin 19. yüzyılda Rusya'nın Kafkasya'yı işgali ve sonrasında yaşadıklarını tanımlamada göç, zorunlu göç, sürgün ve soykırım kavramlarından hangisinin kullanılacağına dair akademisyenlerin ve Türkiye'deki Çerkes diasporasının konuya bakışından örnekler sunmaktadır. Yazar kitap boyunca genellikle Çerkeslerin Rus işgali sonucunda Osmanlı'ya göç ettiği tezini vurgulamasına rağmen (bazı yerlerde bunu sürgün olarak da adlandırmaktadır), Çerkeslerin etnik temizliğe maruz kaldığını, hatta Birleşmiş Milletler'in tanımına göre yaşadıklarının soykırım olarak da adlandırılmasının yanlış olmayacağını belirtmektedir. Bu kavramların yeterince açıklanmaması ve tutarlı olarak kullanılmaması, hem olayın tanımlanması bakımından çelişki yaratmakta hem de terminoloji karışıklığına yol açmaktadır. (s. 148154).

Sonuç bölümünde yazar, konuyu ve kendi argümanlarını pekiştirecek bir sonuç yazısı yerine Circassianworld adlı internet sitesinin sürgün üzerine düzenlediği uluslararası bir tartışmaya katılan akademisyenlerin sözlerine yer vermekte, internette dolaşan bilgilere dayanarak Fahri Korutürk, Ahmet Necdet Sezer, Ali Fethi Okyar, Ali Fuad Cebesoy gibi Çerkes olup olmadığı tam bilinmeyen isimleri sıralamaktadır.

Kitabın sonunda orijinal belgelere yer verilmiştir. Fransızca belgeler kısmında Karantina Cemiyeti'nde görev alan Dr. Barozzi'nin Osmanlı Karantina Cemiyeti'nin yayın organı Gazette Medicale D'orient gazetesinde 27 Temmuz 1864 tarihinde yayınlanan notları ve raporu 
bulunmaktadır. Yazıda 1863 ve 1864 yıllarında onbinlerce Çerkesin Trabzon ve Samsun bölgelerine gelişlerinden, karaya çıktıkları dönemde yaşanan salgın hastalıklardan, çekilen açlıktan, yolculuk şartlarından, Osmanlı devletinin yetersizliği ve bazı görevlilerin durumun vehametini anlamamaları yüzünden günde bine yakın Çerkesin öldüğünden bahsedilmektedir (sayfa 169-207). ilk mektuptaki ifadeye göre, Kasım 1863'ten Temmuz 1864'e kadar Osmanlı topraklarına gelen Çerkes sayısının 300 bin olduğu, bunların üçte birinden fazlasının öldüğü düşünülmektedir (s. 188).

Kitapta göze çarpan en önemli eksiklik, Rusya ve Osmanlı arşivlerindeki binlerce belgeden, o dönemle ilgili Rus asker ve devlet görevlilerinin yazdığı sayısız kitaptan yararlanılmamış olmasıdır. Bu da yazar tarafından birçok genelleme yapılmasına neden olmakta, okuyucu için kimi argümanların ciddiye alınmasını zorlaştırmaktadır. Çerkeslerle ilgili Türkçe ve İngilizce literatürü takip edenler için yeni bir şey söylenmemekte ve hali hazırda var olan çalışmalar yeniden aktarılmaktadır. Ancak yine de farklı yerlerde bulunan çalışmaların bir kitapta toplanıp incelenmesi önemlidir. Kitabın bu alanda bilgisi sınırlı olan İtalyan okuyucu için yazıldığını da göz önünde bulundurmak gerekir. İtalyan okuyuculara Çerkeslerin yaşadığı trajediyi anlatan bir kitap olması bakımından önemlidir. 